\title{
MIEJSCE „OSOBY” W DECYZJI MEDYCZNEJ. ANALIZA ZAGADNIENIA W ŚWIETLE PERSONALIZMU JACQUES'A MARITAINA
}

DOI: http://dx.doi.org/10.12775/SPLP.2019.009

\section{Streszczenie}

Pojęcie decyzji medycznej stanowi moment konstytutywny relacji między pacjentem a opiekunem (np. lekarzem). To spotkanie dwóch osób opiera się na konkretnych zasadach i normach etycznych. W niniejszym artykule autor dokonuje analizy owej problematyki w oparciu o personalizm Jacques'a Maritaina. Badając jego główne założenia antropologiczne, autor konkluduje, że decyzja zależy od tego, jaki mamy obraz rzeczywistości, w tym obraz człowieka. Następnie autor studiuje pojęcie czynu ludzkiego, aby pokazać, iż decyzja pozostaje w ścisłej relacji z wymiarem normatywnym każdego czynu. Analiza zagadnienia doprowadziła do następujących wniosków: godność ludzka nie może być ujęta tylko ontologicznie, lecz także praktycznie (powinny być stosowane dla chorego godne warunki), a moment spotkania powinien mieć wartość terapeutyczną.

Słowa kluczowe: czyn ludzki; decyzja medyczna; godność człowieka; Maritain; osoba; personalizm; rzeczywistość

Role of "Person" in a Medical Decision.

An Analysis in the Light of Jacques Maritain's Personalism

\section{Summary}

The motion of medical decision refers to the foundational moment of the relationship between the patient and the care provider (a doctor, a nurse, a chaplain 
etc.) As such, it is based on the specific principles and the ethical standards. We discuss it from the perspective of Jacques Maritain's personalism. Examining the main anthropological assumptions, the French philosopher shows that the medical depends on how we picture reality, including the concept of a being human. The decision making process comes from an integral and complex view of humanity with its physical and spiritual dimension. Then we analyse the human actions to show that the decisions are related to the normative dimension of what we do. We may conclude that the concept of human dignity is not purely ontological, but it has its consequences in the day-to-day practice. It allows us to improve the patient's conditions and to enable the therapeutic value of the decision making. We must bear in mind that the human being transcends its own intellect and is still open to knowledge (intellect) and love (will). Any medical decision is therefore closely related to the natural human abilities. Therefore, because of our nature and with the help of others, we can make decisions based on objective premises.

Keywords: human act; human dignity; Maritain; medical decision; personalism; person; reality

Relacja między opiekunem (lekarzem, pielęgniarką, kapelanem) a pacjentem ma przede wszystkim charakter interpersonalny, międzyosobowy. Pacjent uczestniczy w tej relacji jako osoba i oczekuje, że zostanie zauważony w swoich pragnieniach, lękach i emocjach. Opiekun jest również człowiekiem w wymiarze osobowym i jest drugą stroną w dialogu z pacjentem. Wspólny punkt obu stron jest więc bardzo wyraźny, a mianowicie ujęcie opiekuna i chorego jako osoby. Takie ujęcie relacji stanowi punkt wyjścia akcji medycznej. Ten fakt traktowania człowieka jako podmiotu i osoby jest stale obecny w każdej sytuacji medycznej i dotyczy wszystkich, którzy uczestniczą w procesie podejmowania decyzji. Centralne znaczenie takiej wizji relacji międzyludzkich znajduje swoje miejsce nie tylko w teorii, ale w sposób szczególny w działaniu, w praktyce. Przestrzeń medycyny uświadamia nam to wyraźnie. Niestety zdarza się, że ujęcie personalistyczne relacji jest zaniedbywane w środowisku medycznym. Moglibyśmy stwierdzić, że nie warto podejmować owej problematyki, ponieważ jest naturalnie wpisana w naturę człowieka. Czymś logicznym jest bowiem fakt, że traktujemy siebie jako osobę. Tym bardziej w kontakcie z chorym w szpitalu. My natomiast stwierdzamy, że często zasady naturalne i podstawowe są kompletnie zanegowane. W związku z tym należy powracać do norm podstawowych, aby odkryć ciągłość zasad etycznych, a także podkreślić logiczne następstwo, że zasady szczegółowe wynikają z zasad pierwszych. Musimy zatem mówić i przypominać o zasadach ogólnych, aby nie uległy one deformacji, a co najgorsze - reinterpretacji. Właśnie dlatego trzeba nam pochylić się nad analizą personalistyczną relacji między ludźmi. W ten sposób chcemy 
nie tylko uwypuklić znaczenie personalistycznej percepcji, ale także pokazać, że ujęcie personalistyczne jest fundamentem, na którym jest zbudowana odpowiednia postawa etyczna, która pozwala zawsze bronić godności każdego pacjenta przed różnymi błędnymi systemami wartości. Relacja w przestrzeni medycznej wyraża się przede wszytkim w czynie, który jest poprzedzony konkretną decyzją. Ten moment spotkania dwóch osób wydaje się nam szczególnie ważny i osobliwy. Dlatego pragniemy dokonać jego analizy w świetle filozofii Maritaina i odpowiedzieć na pytanie: jaki jest związek między decyzją medyczną a działaniem ludzkim i na czym polega jego specyfika? To pytanie już pozwala nam dokonać pewnego założenia, ważnego z punktu widzenia metodologii, a mianowicie, że wymiar personalistyczny jest uważany przez nas jako podstawa komunikacji międzyludzkiej. Wynikają z niej inne wartości, takie jak szacunek, zdolność słuchania i empatii, pragnienie dobra danej osoby, które wyraża się przede wszystkim w decyzjach medycznych i w konsekwencji w konkretnych czynach. Na początku naszej analizy chcemy dokonać pewnej klaryfikacji, istotnej, aby tekst był czytelny. Otóż, mówiąc o opiekunach w przestrzeni medycznej, mamy na myśli wszystkie osoby, które biorą udział w decyzji jako personel medyczny, czyli np. lekarz, pielęgniarka, kapelan, rodzina itp. Te osoby stanowią jedną stronę dialogu i razem z pacjentem podejmują konkretną decyzję medyczną. W niniejszym artykule będziemy czerpać z dorobku Maritaina, który został zgrupowany i tworzy zbiór siedemnastu tomów. Zostały one wydane przez wydawnictwo uniwersytetu we Fryburgu, w Szwajcarii, w latach1986-2007 (CEuvres Complètes de Jacques et Raïssa Maritain, les Éditions Universitaires Fribourg, Suisse).

Pozornie możemy odnieść wrażenie, że Maritain, jako filozof, nie ma nic do powiedzenia w kwestii relacji międzyludzkich w przestrzeni medycznej, szczególnie jeżeli chodzi o podjęcie decyzji medycznej ze strony pacjenta. Filozof francuski koncentruje się w swoich badaniach przede wszystkim na analizie teorii poznania, nowej wizji świata (humanizm integralny) i poezji, omawia zasady dobra wspólnego i analizuje duchowość człowieka na podstawie wielkich mistrzów życia wewnętrznego (św. Jan od Krzyża, św. Teresa z Avila). W jakim zatem stopniu filozofia Jacques'a Maritaina może nam pomóc rozjaśnić omawianą kwestię decyzji medycznej? Wprawdzie nie zajmował się konkretnie owym zagadnieniem, niemniej jednak jego personalistyczne spojrzenie zawiera pewne wskazówki, które ułatwiają podjęcie decyzji obiektywnej, zakorzenionej w realnym i prawdziwym oglądzie każdej sytuacji medycznej. Jego wizja człowieka zakłada nawet konieczność decyzji, która pozwala człowiekowi prowadzić życie zgodnie z jego własną naturą. 


\section{DECYZJA MEDYCZNA A PERSONALIZM MARITAINA}

W punkcie wyjścia trzeba podkreślić, iż w kwestii decyzji etycznej, która jest decyzją zawsze ludzką, człowiek kieruje się pewnymi regułami. Innymi słowy, dla Maritaina akt ludzki zakłada pewne normy. Człowiek żyje i działa zgodnie z tym, jak postrzega siebie. Zdaniem ks. Jacka Grzybowskiego takie ujęcie rzeczywistości, gdzie dane spekulatywne mają swoje specyficzne zastosowanie praktyczne, stanowi podstawę każdej refleksji antropologicznej. W swoich badaniach polski filozof akcentuje szczególnie aspekt podmiotowości człowieka w jej wymiarze społecznym. Niemniej jednak stwierdza, iż „określona wizja antropologiczna winna stanowić punkt wyjścia dla rozważań społecznych"'. Pojęcie osoby i jej przeznaczenie, takie jakie człowiek posiada sam w sobie, nie jest pojęciem neutralnym, ale jest wymiarem praktycznym, który jest wprowadzany w życie przez konkretnego człowieka. Tym samym, jak podkreśla Mirosław Sadowski, koncepcja człowieka ma charakter nie tylko opisowy, ale także nakazuje pewne akty, ma wymiar preskryptywny ${ }^{2}$. Oznacza to, że ma ona swoje zastosowanie jednocześnie teoretyczne, ale także i praktyczne. Jak dobrze wiemy, obraz, jaki posiadamy o nas samych, implikuje nie tylko pewne prawa, ale także wpływa na nasze decyzje i na nasze działanie. Dla Maritaina właśnie personalistyczne spojrzenie jest uważane za niekwestionowany fundament, aby podjąć decyzję i wreszcie przejść do konkretnego działania. W tej perspektywie, według Maritaina, działanie jest następstwem, kontynuacją i manifestacją bytu (,l'action est la suite et la manifestation de l'être") ${ }^{3}$. Maritain wyraźnie stwierdza, że człowiek, zanim zacznie działać, musi „być” (,,il faut être avant d'agir”)4.

Pojęcie człowieka stanowi zatem kryterium, za pomocą którego podejmujemy decyzję zarówno jako lekarz, pielęgniarka, kapelan, jak i pacjent. Zwróćmy więc naszą uwagę na najważniejsze idee, na których Maritain buduje swój personalizm. Jego podstawowym odniesieniem jest realizm metafizyczny św. Tomasza z Akwinu. Stąd podkreśla rolę rozumu, uważanego za naturalną zdolność do osiągnięcia prawdy samej w sobie. W swojej teorii wiedzy, to przede wszystkim intuicja bytu pozwala nam dostrzec rzeczywistość samą w sobie. Ujęcie rzeczywistości na sposób intuitywny wydaje się niezbędne, ponieważ dla Maritaina rzeczywistość jest nie tylko ujmowana w swym wymiarze materialnym, ale jest

J. Grzybowski, Jacques Maritain i nowa cywilizacja chrześcijańska, Fronda, Warszawa 2007, s. 189.

2 Por. M. Sadowski, Personalizm chrześcijański Jacques'a Maritaina jako fundament koncepcji godności człowieka, http://www.bibliotekacyfrowa.pl/Content/35301/0004.pdf (17.05.2019).

3 J. Maritain, Antimoderne, CEuvres Complètes, tom II, 1987, s. 1063.

4 Tamże, s. 1025. 
ona także analizowana przez pryzmat pierwszych zasad i pierwotnego znaczenia każdego czynu. W tej perspewtywie Maritain wprowadza pojęcie rzeczywistości ekstramentalnej (la réalité extramentale). Oznacza to, że rzeczywistość jest niezależna od umysłu, który ją pojmuje. W tym ujęciu rzeczywistość zewnętrzna posiada cechę autonomii w stosunku do ducha, ponieważ każda rzecz zawiera w sobie konkretną treść inteligiblną, jeszcze zanim zostanie ona opracowana przez zdolności poznawcze człowieka ${ }^{5}$. Innymi słowy, przed poznaniem rzecz już ma w sobie konkretną materię poznawczą. Jest to pierwszy, bardzo ważny, punkt w podejmowaniu decyzji, w którym człowiek naprawdę patrzy na sytuację w swojej złożoności: widzi świat zewnętrzny (cierpiącego pacjenta), ale także postrzega duchowy aspekt tego świata: godność pacjenta, jego duchowość, jego partykularność, historię życia, warunki, które zniekształcają poczucie sensu życia, kruchość (fragilité) egzystencji pojmowana nie jako niebezpieczeństwo, ale raczej jako jeden z podstawowych wymiarów człowieka.

Następnie Maritain zauważa, że konieczne jest odróżnienie osoby od jednostki. Te dwa wymiary nie kolidują ze sobą ${ }^{6}$ Należy jednak pamiętać o ich wyjątkowej funkcji, ponieważ złe zrozumienie specyfiki między nimi może zniekształcić decyzję. Człowiek jako jednostka jest związany z procesami właściwymi dla materii zgodnie z zasadą indywidualizacji. W tym sensie człowiek jest częścią wszechświata, fragmentem materii. Maritain mówi nam: „Jako jednostki podlegamy gwiazdom. Jako ludzie dominujemy nad nimi"’7. Z drugiej strony, dzięki aspektowi personalistycznemu, człowiek jest istotą duchową. Człowiek ma zatem duszę, swoisty element boski, poprzez który byt ludzki stanowi sam w sobie świat autonomiczny. Co więcej, w wymiarze personalistycznym stanowi on świat przewyższający świat materialny. W tej perspektywie, jak zauważa Wiktor Kołodziejczak, będąc światem duchowym i wolnym, a więc także moralnym, osoba jest pojęciem, które dotyczy istot ukierunkowanych na jakiś konkretny cel ${ }^{8}$. To człowiek wybiera nawet środki i metody, aby ów cel osiągnąć. Oczywiście istnieją okoliczności łagodzące, które wpływają na zdolność człowieka do zarządzania własnym życiem. Niemniej jednak wymiar duchowy pozostaje nienaruszalny, a ostateczna decyzja medyczna nie może go lekceważyć, ponieważ ten wewnętrzny aspekt (dusza niematerialna) ukazuje nam godność właściwą człowiekowi. Z tej

5 Por. J. Maritain, Sept leçons sur l'être et les premiers principes de la raison spéculative, Euvres Complètes, tom V, 1982, s. 545.

6 Rozróżnienie między osobą a jednostką u Maritaina akcentuje ks. Stanisław Kowalczyk. Zdaniem polskiego filozofa, ma ono ogromne znaczenie, aby wyjaśnić wymiar społeczny bytu ludzkiego. Por. S. Kowalczyk, Człowiek i społeczność. Zarys filozofii społecznej, Wyd. KUL, Lublin 2005, s. 126; tenże, Wprowadzenie do filozofii J. Maritaina, Wyd. KUL, Lublin 1992.

7 J. Maritain, Trois Réformateurs, Luther - Descartes - Rousseau, Euvres Complètes, tom III, 1984, s. 453.

8 Por. W. Kołodziejczak, Jacques Maritain - u źródeł współczesnych koncepcji praw człowieka, „Studenckie Zeszyty Naukowe”, 26(18)2015, s. 17-25. 
perspektywy towarzyszenie choremu w podjęciu decyzyji polegałoby na działaniu, które umożliwia pacjentowi ponowne odkrycie wartości własnej tożsamości przy jednoczesnym tworzeniu bardziej humanitarnych warunków w przypadku choroby (rozwój medycyny paliatywnej, obecność rodziny, spojrzenie wspólnoty i społeczeństwa na daną chorobę itd.). Musimy wyraźnie stwierdzić, że rola społeczeństwa polega na tym, że powinno ono gwarantować między innymi sprawiedliwe warunki życia moralnego i intelektualnego. Pojęcie osoby zakłada zatem pomoc innych, aby się spełnić i osiągnąć własną osobowość. W tym sensie zagrożeniem dla człowieka jest indywidualizm, który waloryzuje jednostkę ze szkodą dla osoby.

Kolejny aspekt, który wydaje nam się niezbędny, gdy spojrzymy na kwestię decyzji medycznej, dotyczy dwóch typowo ludzkich zdolności: inteligencji i miłości. Dla Maritaina, dzięki tym dwóm wymiarom, człowiek jest w stanie przekroczyć świat materialny, a nawet przewyższyć własną egzystencję. W swoich analizach wyjaśnia nam, że człowiek jest jednostką, która trzyma sama siebie w rękach przez inteligencję i wolę. Piotr Wasyluk, badając koncepcję realizmu dziejowego u Maritaina, słusznie podkreśla, iż świadomość ludzka wzrasta wraz „z postępem ludzi zarówno w sferze wartości duchowych (np. wolności), jak również wartości poznawczych (rozwój wiedzy filozoficzej i naukowej)" ". Człowiek nie istnieje tylko na sposób fizyczny, lecz przekracza swoje istnienie (surexister) duchowo poprzez inteligencję i poprzez miłość, do tego stopnia, że jest w pewnym sensie wszechświatem samym w sobie, mikrokosmosem, w którym cały wielki wszechświat może być zawarty przez wiedzę. Natomiast poprzez miłość człowiek może całkowicie oddać się innym bytom ludzkim, które są w relacji do niego także odrębne i stanowią świat odrębny, swoisty mikrokosmos. Niemniej jednak relacja inteligencji i miłości, istniejąca między ludźmi, nie ma żadnego odpowiednika, jaki można by było znaleźć w świecie fizycznym ${ }^{10}$. Stwierdzamy zatem, że człowiek dla Maritaina jest przede wszystkim istotą dynamiczną, która rozwija swoją osobowość poprzez rozum i wolę. W tej perspektywie Maritain stwierdza, że „człowiek nie będzie w pełni osobą, per se subsistens i per se operans, jak tylko w takim stopniu, w jakim życie rozumu i wolności będzie dominować w nim nad zmysłami i namiętnościami”" ${ }^{\prime 1}$. W przeciwnym razie stanie się niewolnikiem okoliczności i przyjemności, a następnie nie będzie zdolny ani do tego, aby decydować o sobie samym, ani do tego, aby posiąść siebie samego. W tej perspektywie rozum i wolność odróżniają człowieka nie tylko od zwierzęcia, ale także od prostego i zredukowanego pojmowania człowieka jako jednostki ${ }^{12}$. W tej optyce Maritain

P. Wasyluk, Między optymizmem i pesymizmem dziejowym - Jacques'a Maritaina koncepcja realizmu historiozoficznego, „Roczniki Filozoficzne”, 60(2012)2, s. 5-23.

10 Por. J. Maritain, Principes d'une politique humaniste, Cuvres Complètes, tom VIII, 1989, s. 188; tenże, Court traité de l'existence et de l'existent, Euvres Complètes, tom IX, 1990, s. 70-71.

11 Tenże, Trois Réformateurs, Luther-Descartes - Rousseau, dz. cyt., s. 456.

12 Por. tamże, s. 456. 
chce pokazać, że człowiek opanowuje życie uczuciowe i emocjonalne poprzez życie inteligencji i miłości. Decyzja kierowana przez intelekt wymaga oglądu najbardziej obiektywnego każdej sytuacji medycznej. W tym celu decyzja wymaga odwołania się do stanowiska innych, w szczególności do opinii osób kompetentnych, które poprzez fakt wykonywania pewnych zadań, mogą pomóc w dokonaniu wyboru najbardziej obiektywnego w danej sytuacji. W tym sensie, nawet jeśli pacjent traci zdolność intelektualną, to jego otoczenie, w szerokim tego słowa znaczeniu, pomaga mu wybrać. Nie chodzi o zastąpienie go, ale o stworzenie relacji zaufania i życzliwości, a także o zachowanie właściwego znaczenia powołania wszystkich osób towarzyszących (lekarza, pielęgniarki, kapelana). Niemniej jednak, istnieje jeszcze inny wymiar zagadnienia, które jest przedmiotem naszych badań. Prawdą jest, że decyzja medyczna zależy od zdolności posiadania samego siebie poprzez intelekt i wolę. Natomaist to, co jest jeszcze istotne, to nie tylko decyzja, ale także rozwój osobowości przez całe życie danej osoby (pacjenta, lekarza, kapelana itp.). W tej perspektywie decyzja medyczna jest uważana za punkt końcowy tego rozwoju. Maritain wyraźnie mówi nam, że osobowość ,rośnie w takim stopniu, w jakim dusza, wznosząc się ponad świat zmysłów, związuje się ściślej przez inteligencję i wolę, z tym co tworzy życie ducha"13. Dotykamy tutaj całej przestrzeni życia duchowego, w której religia zajmuje ważne miejsce w kształtowaniu i rozwoju osobowości.

W swojej refleksji nad „osobą” Maritain podkreśla cechę autonomii szczególnie w działaniu. Niemniej jednak zawsze podkreśla konieczność jej afirmacji w relacji do innych bytów. $W$ ten sposób wartości duchowe zawsze przewyższają wartości ekonomiczne i techniczne ${ }^{14}$. Z punktu widzenia metafizyki, Maritain podkreśla klasyczną koncepcję osoby jako byt substancjalny, niezależny w istnieniu, indywidualny, autonomiczny i racjonalny. To ujęcie osoby jest ściśle zakorzenione w rzeczywistości. Co więcej, pomaga nam poprawnie odczytać rzeczywistość na drodze poznania intuicyjnego ${ }^{15}$. W tym kontekście mówimy o realizmie metafizycznym u św. Tomasza z Akwinu. Takie ujęcie osoby pozwoliło Maritainowi zachować związek prawdy z rzeczywistością i w konsekwencji uniknąć redukcji osoby tylko do wymiaru materialnego. Człowiek jest zatem zdolny poznać prawdę i działać autonomicznie. W ten sposób może zarządzać swoim życiem. Ten aspekt personalizmu Maritaina jest istotny, zwłaszcza jeżeli chodzi o osobiste zaangażowanie chorego. Poprzez rozum człowiek może dostrzec istotę rzeczy i otaczającą go rzeczywistość. Z drugiej strony, przez autonomię, człowiek jest wolny i posiada

13 Tamże, s. 456.

14 Por. A. Lendzion, Koncepcja podmiotu osobowego w personaliźmie Jacques'a Maritaina, „Roczniki Pedagogiczne", 2(2010)38, s. 5-20.

15 Por. T. Michałek, Jacques'a Maritaina koncepcja „,szóstej drogi”, „Roczniki Filozoficzne”, 43/44(1995-1996)2, s. 135-159. 
siebie $^{16}$. Zatem w relacji ze światem zewnętrznym osoba afirmuje siebie poprzez rozum, który poznaje, poprzez wolne działanie (wola człowieka), a także poprzez relacje z innymi. Właśnie z powodu tej specyfiki człowiek wyraża siebie, jako byt osobowy przez całe swoje życie ${ }^{17}$. Człowiek przekracza świat widzialny w tym znaczeniu, że jest w stanie zarówno przekroczyć swoje instynktowne działania, jak i otworzyć się intencjonalnie na innych ludzi i na Absolut. Z jednej strony odkrywa wymiar immanentny, swoje wnętrze, autonomię i umiejętność panowania nad sobą samym. $Z$ drugiej zaś strony pozostaje w stałej relacji z innymi ludźmi. Człowiek zatem odkrywa swoją podmiotowość i pokazuje ją poprzez swoje czyny, szczególnie poprzez naturalną skłonność do dobra, do którego dąży ${ }^{18}$. Powyższe analizy prowadzą nas do istotnej konkluzji, a mianowicie człowiek odkrywa samego siebie w swoim działaniu jako ten, który jest podmiotem, ale także jest przedmiotem swojego działania. Podjęcie decyzji medycznej ilustruje nam tę prawdę dokładnie, ponieważ w obliczu wyboru jest on zawsze podmiotem, ale jednocześnie wybór wpłynie na jego egzystencję. Byt ludzi jest zatem przedmiotem, w znaczeniu, że ponosi konsekwencję swojej decyzji i swojego działania. Oczywiście, wybór zawsze zależy od kontekstu czasu, przestrzeni i innych okoliczności. Niemniej jednak wymiar personalistyczny wymaga, aby brać pod uwagę duchowy i cielesny aspekt człowieka, gdzie wymiar wewnętrzny jest źródłem świadomej aktywności i kieruje człowieka w stronę celu najwyższego. Nie oznacza to, że ciało traci swoje znaczenie, lecz jest ściśle zjednoczone z duchem i jako takie musi być szanowane. Zachowanie harmonii cielesno-duchowej zatem pozwala nam uniknąć pewnych niebezpieczeństw, które wynikałyby z tego, że człowiek jest zredukowany do rzeczy, a jego transcendencja jest zaniedbana. Kładziemy nacisk na konieczność integralnej wizji osoby, aby postrzegać wartość ludzkiej egzystencji tak samo w jej duchowym wymiarze, jak i w cielesnym, ponieważ choroba obejmuje również te wszystkie wymiary człowieka ${ }^{19}$. Dlatego opiekun, np. lekarz, biorąc pod uwagę swoje umiejętności zawodowe musi być wrażliwy na duchowy wymiar pacjenta. Interwencja medyczna dotyczy nie tylko działań technicznych, ale całej osoby. Dlatego nie możemy zapomnieć o wszystkich aspektach, które powyżej analizowaliśmy i odseparować człowieka od jego duchowości, emocji, uczuć. Przypominanie o tym jest być może jeszcze bardziej konieczne w dzisiejszych czasach. Obecnie, gdy medycyna rozwija swoje badania

16 Por. M.-F., Colliere, L'apport de l'anthropologie aux soins infirmiers (note de recherche), „Anthropologie et Société", 14(1990)1, s. 115-123.

17 Por. J.-F. Petit, Philosophie et théologie dans la formation du personnalisme d'Emmanuel Mounier, Les Éditions du Cerf, Paris 2006, s. 234-236.

18 Por. R. Andorno, La bioéthique et la dignité de la personne, Coll. « Médecine et Société », Presses Universitaires de France, Paris 1997, s. 35.

19 Por. F., Niessen, O., De Dinechin, Repères chrétiens en bioéthique, la vie humaine du début à la fin, Editions Salvator, Paris 2015, s. 62. 
i specjalizuje się w metodach technicznych, ważne jest to, aby podkreślić integralność osoby ludzkiej. W ten sposób może ona zachować swoje szczególne i specyficzne miejsce w relacjach medycznych, a decyzja będzie zawsze oparta na dobru osoby.

Personalistyczna wizja człowieka w ujęciu Jaques'a Maritaina pokazuje wspólny wymiar osobowy, który jest obecny w każdym człowieku. Ten niepodważalny fakt pomaga nam traktować chorych, jako tych, którzy mają swoją godność, pomimo tego, że może nie czują jej z powodu choroby czy bólu²0. Taka perspektywa relacji ma również konsekwencje etyczne, które wyrażają się w decyzji medycznej. Innymi słowy, akt medyczny lub spotkanie z pacjentem nie są etycznie obojętne. Mają one charakter moralny, który mobilizuje nas do traktowania innych jako osoby posiadające wartość samą w sobie. W tej perspektywie obraz choroby i cierpienia nie może usprawiedliwiać zaniedbań relacji międzyludzkich i bagatelizowania decyzji medycznej. Słusznie zauważa ks. Wojciech Cichosz, że „J. Maritain budując swą koncepcję człowieka zawsze ma na uwadze cały ludzki byt" ${ }^{\prime 2}$. Personalistyczny charakter relacji z pacjentem pozwala zrozumieć zarówno specyficzną pozycję człowieka wśród innych stworzeń, jak i jego wyjątkową wartość istnienia. Wszystkie powyższe elementy konstytuujące osobę wpisane są w każdego człowieka i stanowią o jego niezbywalnej godności. Dlatego też negacja któregokolwiek z tych elementów przez lekarza, pielęgniarkę czy kapelana utrudniłaby jego służbę, a nawet zniekształciłaby relację zaufania, która jest niezbędna w decyzji medycznej.

\section{DECYZJA MEDYCZNA A POJECCIE CZYNU LUDZKIEGO W PERSONALIZMIE MARITAINA}

Istnieje ścisły związek pomiędzy decyzją a konkretnym czynem. Dokonany wybór prowadzi naturalnie do czynu w celu zrealizowania owej decyzji. Niemniej jednak istnieje niebezpieczeństwo, że decyzja, bez konkretnego odniesienia do właściwych norm, może zniekształcać działanie ludzkie. Wobec tego trzeba ją zawsze traktować w świetle konkretnej koncepcji osoby, która stanowi normę personalistyczną. To właśnie ta norma wskazuje nam kierunek, w którym działanie zmierza w swych najgłębszych tendencjach. Zdaniem francuskiego filozofa „działać” oznacza „być” w pewien sposób, ale także przepełniać swoją bytowość. Kto mówi „działanie”, mówi o pewnej pełni, o pewnym rozkwicie, a dokładniej -

20 Por. F. Rognon, Vers une éthique de la vulnérabilité. Responsabilité face à la haute technicité et reconnaissance du sujet, w: Souhaitable vulnérabilité ?, red. M. Jo-Thiel, Coll. Chemins d'éthique, Presses Universitaires de Strasbourg, Strasbourg 2016, s. 69-78.

21 W. Cichosz, Implikacje pedagogiczne antropologii Maritaina, „Studia Gdańskie”, 13(2000), s. $159-173$. 
o pewnej emanacji, dzięki której byt się realizuje ${ }^{22}$. W tej perspektywie działanie ludzkie jest rozumiane nie tylko ,na zewnątrz”, przez mowę lub gesty. Nie wyczerpuje to całego swojego bogactwa. Czyn ludzki jest również ujmowany od „wewnątrz”, przez inteligencję, przez jej skłonność do prawdy, piękna i dobroci. W tym kontekście decyzja medyczna powinna być kompatybilna z naturalnymi tendencjami człowieka, tak aby wyrażała ową pełnię egzystencjalną.

To rozróżnienie między działaniem wewnętrznym (inteligencja i miłość) a zewnętrznym (cielesność) nie oznacza oddzielenia człowieka od ludzkiego działania. Wręcz przeciwnie, działanie stanowi „całość” (wola, inteligencja, a nie tylko emocje i poruszenia zmysłowe) w bycie ludzkim jako duchowym podmiocie. Te dwa wymiary skupiają się w człowieku i mają wpływ na jego własne istnienie. Stąd też decyzja medyczna powinna zostać podjęta w oparciu o oba wymiary. Wówczas nie przesłania nam właściwego obrazu człowieka jako osoby i jej podstawowych wartości. Innymi słowy nie dochodzi do zniekształcenia człowieka jako osoby.

Kolejnym istotnym elementem decyzji medycznej jest jej zgodność z konkretnym przedmiotem czynu. Z punktu widzenia metafizyki, w każdej rzeczy jest obecny wymiar inteligibilny, który istnieje nawet poza umysłem. Jest to właśnie rzeczywistość ekstramentalna (la réalité extramentale). Konieczne jest zatem, aby rozum był z nią zgodny. W tej perspektywie człowiek działa dobrze, pod warunkiem, że rozum jest ukierunkowany na pierwotną rzeczywistość rzeczy. Istnieje pewien porządek, który jest miarą dla rozumu i ostatecznie mierzy również działanie, ponieważ porządek ten pokazuje zgodność rzeczy z wymogami jej natury, aby przekazać ten obiektywny obraz rozumowi. Ten porządek, który reguluje rozum i ludzkie działanie, Maritain nazywa prawem naturalnym ${ }^{23}$. Działanie zatem nie jest pozbawione tego porządku i wpisuje się w jego oddziaływanie. Edward Niesyty stwierdza, że prawo naturalne stanowi wymóg każdego działania. Jest ono „rodzajem celu wyrastającego z głębin życia w ogóle i z głębin człowieczeństwa"24. Zauważamy więc, że decyzja nie może zaprzeczać owemu porządkowi, lecz go wyrażać.

Maritain precyzuje, że każdy akt typowo ludzki zawiera dwa elementy: ontologiczny i gnozeologiczny. Oba wymiary czynu mają swoją rolę do spełnienia w procesie podejmowania decyzji. Mówiąc o elemencie gnozeologicznym, kładziemy nacisk zarówno na ludzkie zdolności poznania prawa naturalnego, ale również akcentujemy fakt, że człowiek jest naturalnie zdolny, aby to prawo zaaplikować w swoim istnieniu. Decyzja medyczna opiera się zatem na tym osobliwym i partykularnym wymiarze poznawczym człowieka. Zdaniem Maritaina

22 Por. J. Maritain, Antimoderne, dz. cyt., s. 1062.

23 Por. J. Maritain, La loi naturelle ou la loi non écrite, Euvres Complètes, tom XVI, 1999, s. 698.

24 E. Niesyty, Miejsce i rola personalistycznej koncepcji spoleczeństwa demokratycznego w humanizmie integralnym Jacques'a Maritaina, Instytut Filozofii UAM, Poznań 2005, s. 126. 
wyjątkowość poznania prawa naturalnego polega na tym, że nie jest ono ujęte w sposób teoretyczny, ani abstrakcyjny, ani przez intelektualny wysiłek konceptualizacji. Poznanie to dokonuje się dzięki naturalnej inklinacji i skłonności natury ludzkiej, która jest w stanie spostrzec prawo naturalne. Decyzja zatem nie opiera się tylko na zmysłowym oglądem rzeczywistości, ale przede wszystkim na intelektualnym i naturalnym ujęciem wartości egzystencjalnych. Moment decyzji zatem jest kompatybilny z naturalnymi inklinacjami człowieka, jego instynktami i dążeniami ${ }^{25}$. Zauważamy więc istnienie niezbędnej i spójnej relacji między ludzkim działaniem a jego naturalną zdolnością poznawczą, co ma swoje przełożenie na konkretne decyzje.

Element ontologiczny orientuje także decyzję medyczną, w ten sposób, aby nie zniekształcała czynu ludzkiego. Działanie człowieka zawiera strukturę normatywną, która ma swoje źródło w ontologicznej rzeczywistości. Posiada ono „,normalność funkcjonowania" (normalité de fonctionnement), która opiera się na istnieniu danego bytu. To zatem ten wymiar Maritain pojmuje jako element ontologiczny. W tym przypadku wyrażenie „formuła idealna” oznacza obiektywną strukturę, która pokazuje człowiekowi kierunek jego działania ${ }^{26}$. W tej perspektwie decyzja musi być zgodna z celem i z przedmiotem danego czynu, który jest wymagany przez samą naturę tego czynu. Św. Tomasz z Akwinu mówi, że dobro moralne opiera się na dobru ontologicznym ${ }^{27}$. Oznacza to, że wartość moralna czynu zależy od dobra przedmiotu danego czynu. Tak więc element ontologiczny prawa naturalnego ujawnia się jako coś, co powinno zostać zrobione, a nie jako coś, co już zostało zrobione; stanowi on pewien porządek, który wyznacza, co jest odpowiednie, a co nie, co jest właściwe człowiekowi i to, co go kształtuje. W sensie ontologicznym prawo naturalne zawiera normy moralne, które są specyficzne tylko dla człowieka jako człowieka ${ }^{28}$. Owa konkluzja jest fundametalna w procesie podejmowania decyzji, ponieważ odkrywa nam prawo naturalne, które nie narzuca się w działaniu ludzkim, lecz prezentuje się w swojej idealnej formule i jako takie ukierunkowuje człowieka na pewne akty moralne. Prawo naturalne jest zatem u człowieka prawem moralnym. Innymi słowy, dzięki swoim normatywnym zdolnościom, prawo naturalne stanowi strukturę, która uwrażliwia człowieka i mobilizuje go do moralnego działania. W tej perspektywie prawo naturalne

25 Por. J. Maritain, La loi naturelle ou la loi non écrite, dz. cyt., s. 711.

26 Por. tamże, s. 703.

27 Por. Św. Tomasz z Akwinu, Summa Theologiae, Ia II $^{\text {ae }}$, q. 18, a. 1-2. Maritain również omawia kwestię przedmiotu czynu, podkreślając, że jest on podstawowym wymiarem dobra danego czynu. Por. J. Maritain, Neuf leçons sur les notions premières de la philosophie morales, Téqui, Paris 1951, s. 31-32.

28 Por. J. Maritain, Natural Law and Moral Law, w: Moral Principles of Action. Man's Ethical Imperative, red. R.-N. Anshen, Coll. Science of Culture Series, Volume VI, Harper and Brothers, New York 1952, s. 62. 
angażuje człowieka moralnie, aby ten mógł działać w harmonii ze swoją własną istotą. W momencie podjęcia decyzji nie można pominąć tego faktu. Zauważamy zatem, iż decyzja medyczna powinna brać pod uwagę element ontologiczny, aby działanie ludzkie wyrażało zawsze przedmiot właściwy danemu czynowi. Na przykład decyzja o eutanazji zakłada konkretne czyny. Niemniej jednak, działanie to stoi zawsze w sprzeczności z naturalnymi inklinacjami ludzkimi, aby żyć. W tym przypadku decyzja prowadzi do czynu, który stoi w sprzeczności z przedmiotem czynu i z jego strukturą normatywną, wpisaną w ten czyn.

\section{ZNACZENIE GODNOŚCI LUDZKIEJ W DECYZJI MEDYCZNEJ}

Pojęcie godności ludzkiej wydaje nam się najbardziej odpowiednie, aby opisać przejście od refleksji teoretycznej i spekulatywnej nad osobą do jej zastosowania w praktyce. Według Maritaina świat wartości obiektywnych gwarantuje ochronę osoby ludzkiej ${ }^{29}$. Ich utrata może zagrozić istnieniu samego człowieka i w konsekwencji doprowadzić do indywidualizmu czy redukcjonizmu. Godność, jako uniwersalna wartość ludzkiej istoty, zobowiązuje nas do uznania i poszanowania jej w każdym człowieku. Ks. Bogusław Król słusznie podkreśla wymiar duchowy, jako ten, który decyduje o specyfice egzystencji ludzkiej i jej godności: „duchowość sprawia, że człowiek jest nie tylko immanentny, ale także transcendentny wobec otaczającego go świata" ${ }^{30}$. Niemniej jednak, takie thumaczenie jest niejasne w obliczu cierpienia. W relacji z osobą chorą nie wystarczy bowiem thumaczenie teoretyczne, że posiada wartość uniwersalną. Francuski filozof Éric Fiat przedstawia dwa znaczenia pojęcia godności: ontologiczne i posturalne. W tej perspektywie potrzebujemy dwóch wymiarów godności. Musimy zarówno uznać godność każdej osoby, jak i stworzyć godne warunki, aby pacjent nie stracił poczucia swojej własnej godności. Owe warunki gwarantują wszyscy, którzy podejmują decyzję w przetrzeni medycznej, zarówno personel, rodzina, jak i sam chory. Éric Fiat podkreśla szczególne znaczenie relacji ${ }^{31}$. Jego zdaniem, pomimo tego, że nie wszyscy podzielają te same przekonania religijne czy światopoglądowe, możliwe jest wspólne potwierdzenie godności każdego człowieka. W tym celu należy podkreślić wpływ Kanta, który podkreśla uniwersalność prawa moralnego u każdego człowieka. Obowiązkiem lekarza i kapelana jest zatem pomoc w odzyskaniu poczucia godności i potwierdzeniu jej w każdym przypadku medycznym. Tylko wówczas decyzja

29 Por. tenże, Les Droits de l'homme et la loi naturelle, Euvres Complètes, tom VII, 1988, s. 670.

30 B. Król, Osobowość, wolność i rozumność człowieka w świetle wybranych dziet Jacques'a Maritaina, „Studia Teologiczno-Historyczne Śląska Opolskiego”, (2014)34, s. 53-66.

31 Według autora bycie w relacji z innymi oznacza mieć kogoś, kto gwarantuje człowiekowi godność i uznaje go w sytuacji cierpienia. É. Fiat, Petit traité de dignité. Grandeurs et misères des hommes, Larousse, Paris 2010, s. 34-38. 
pacjenta staje się wyborem realnym i obiektywnym. Choroba może być czynnikiem, poprzez który człowiek traci poczucie własnej godności. W tej sytuacji nie wystarczy powiedzieć, że ktoś jest godny. Konieczne jest stworzenie godnych warunków egzystencji w danej sytuacji: obecność bliskich, jakość opieki medycznej, czas poświęcony choremu itp. To spostrzeżenie Érica Fiata ma fundamentalne znaczenie, ponieważ obliguje człowieka, aby w swoich działaniach podkreślał nieustannie centralne miejsce godności ludzkiej² ${ }^{32}$ Godność pozostaje zatem ściśle związana z każdym człowiekiem i jest podstawową, aksjologiczną kategorią relacji między opiekunem a pacjentem. Pozwala nam to zachować równowagę w technologii medycznej i nie stracić z oczu człowieka postrzeganego w całości. Niebezpiecznie jest izolować problemy techniczne związane z chorobą od integralnej wizji, obejmującej wszystkie istotne aspekty podmiotu personalistycznego ${ }^{33}$. Bez tego podstawowego odniesienia się do szacunku dla godności osoby, trudno wyobrazić sobie troskę o człowieka i jego ciało. Maritain podkreśla potrzebę zarówno intelektualnej, jak i moralnej rewolucji, która przywróciłaby prawdziwą wiarę w ludzką godność i prawa człowieka. W tym celu francuski filozof mówi o konieczności powrotu do przesłania ewangelicznego, które ukazuje nam człowieka w całej prawdzie: jako istotę wyjątkową (rozum, wolna wola), a także jako stworzenie osłabione przez grzech pierworodny, które potrzebuje pomocy ze strony Boga poprzez łaskę. Niemniej jednak Objawienie przedstawia także człowieka w jego transcendentnym wymiarze, który pozwala nam zarazem odkryć na nowo wiarę w człowieka, a także wzbudzić świadomość ludzkiej godności i praw człowieka ${ }^{34}$. W związku z tym, poszanowanie godności jest podstawową zasadą w spotkaniu z pacjentem, ponieważ pozwala ono zawsze patrzeć na człowieka w jego złożoności i zachowywać czujność w obliczu postępu technicznego medycyny ${ }^{35}$. Niemniej jednak, nie możemy zatrzymać się nad znaczeniem ontologicznym, ale musimy zobaczyć, w jaki sposób jest ono wprowadzane w praktyce, w działaniach medycznych. Jacques Maritain twierdzi, że człowiek afirmuje swoją godność poprzez autonomiczną i wolną decyzję ${ }^{36}$. Godność pozwala rozpoznać w każdym człowieku zdolność oceny każdej sytuacji za pomocą sumienia. Niemniej jednak, posiada ona także wymiar dialogu, aby drugi człowiek stał się gwarantem godności chorego.

Nie ulega wątpliwości, że troska i szacunek należny osobie wynikają przede wszystkim ze szczególnej godności osoby. Chociaż człowiek jest w stanie

32 Por. É. Fiat, Petit traité de dignité, dz. cyt., s. 84.

33 Por. Jean Paul II, Le discours aux chirurgiens polonais, 11 février 1992, „L'Osservatore Romano”, 13(1992), s. 29-30.

34 Por. J. Maritain, Les Droits de l'homme et la loi naturelle, dz. cyt., s. 662.

35 Por. Benoît XVI, Discours à l'Académie pontificale pour la vie, le 13 février 2010, https://w2.vatican.va/content/vatican/fr.html (14.05.2019).

36 Por. F.-J. Mazurek, J. Maritaina koncepcja Praw Człowieka, w: Jacques Maritain prekursor soborowego humanizmu, red. E. Balawajder, S. Kowalczyk, Wyd. KUL, Lublin 1992, s. 155-169. 
przekraczać swoje istnienie, jego życie również doświadcza czasowości i kruchości ludzkiej egzystencji. Doświadczamy tego szczególnie w sytuacji cierpienia i choroby. Zasadniczym aspektem naszej refleksji nad godnością ludzką jest fakt, że choroba dotyka nie tylko ciało, ale człowieka jako całość, w jego związku cielesno-duchowym ${ }^{37}$. Lekarz, pielęgniarka, kapelan idą do pacjenta, będąc świadomymi nie tylko integralnej i ontologicznej wizji człowieka, ale także jego potrzeb i pragnienia godnego życia. Pojęcie osoby jest akcentowane u Maritaina, aby chronić człowieka przed rozmaitymi formami totalitaryzmów i wynaturzeń ${ }^{38}$. Decyzja medyczna zatem wpisuje się w tę dialektykę. Innymi słowy, opiekun widzi w pacjencie nie tylko osobę, ale także i kolejne implikacje, czyli odnosi się do człowieka jako podmiotu, a godność pacjenta uznaje za formę ochrony człowieka w jego kruchości, co wyraża się właśnie w decyzji medycznej.

Istnieje jeszcze inny związek między pojęciem godności, działaniem ludzkim, a decyzją medyczną. Otóż, według Maritaina, wolność i rozumność, charakterystyczne dla człowieka, są podstawą ludzkiej godności. Przyjmując dobrowolnie prawo naturalne, człowiek wzmacnia poczucie swojej godności ${ }^{39}$. Oczywiście, byt ludzki, podkreślmy to wyraźnie, nie może stracić godności, lecz jej poczucie. Człowiek może utracić sens własnej egzystencji i w konsekwencji stwierdzić, że stracił własną godność. W takiej sytuacji trzeba podkreślić konieczność kształtowania swojej osobowości w ciągu całego życia. Ten wymiar nieustannego wysiłku, aby uformować w sobie pewne zachowania, stanowi istotny element, który ma konkretny wpływ na decyzję. Poprzez cnoty moralne i intelektualne, a także poprzez życie duchowe człowiek wypracowuje w sobie pewien obraz własnej egzystencji, jednocześnie widząc celowość swoich czynów. Biorąc pod uwagę ten aspekt spostrzegamy, że inaczej postąpi osoba duchowo uformowana, a inaczej ateista. Czasami decyzje są diametralnie różne, w zależności od wartości, na których człowiek opierał swoje życie. Powyższa analiza pozwala nam stwierdzić, że personalizm Maritaina ma charakter dynamiczny. Człowiek, dzięki własnemu zaangażowaniu, może stać się „bardziej człowiekiem”. Oznacza to, że jego egzystencja zależy od niego samego. Dlatego też człowiek spełnia się nie tylko wówczas, kiedy realizuje swoje plany, ale także wtedy, kiedy jego czyny są zgodne z prawem naturalnym. Pozornie możemy stwierdzić, że prawo naturalne jest ciężarem, który ogranicza ludzką wolność. Tezę taką stawia między innymi francuski filozof i politolog Luc Ferry ${ }^{40}$. Tymczasem prawo naturalne stanowi ten wymiar, który umacnia poczucie godności. Ono wyzwala z człowieka jego własną esencję, aby działanie było zawsze zgodne z naturą człowieka. Innymi słowy, prawo naturalne nadaje kierunek działaniu, które jest zawsze na korzyść dla czło-

37 Por. T. Collaud, Le statut de la personne démente, Academic Press Fribourg, Fribourg 2003, s. 68.

38 Por. J. Maritain, Les Droits de l'homme et la loi naturelle, dz. cyt., s. 668.

39 Por. tenże, Raison et raisons, Euvres Complètes, tome IX, 1990, s. 361.

40 Por. L. Ferry, The New Ecological Order, University of Chicago Press, Chicago 1995, s. 3-5. 
wieka. Tym samym, może ono rozwijać i wzmacniać poczucie jego godności. Według Grégora Puppincka koncepcja prawa naturalnego Maritaina wpłynęła na ostateczną wersję Powszechnej Deklaracji Praw Człowieka. Francuski prawnik słusznie zauważa, że Maritain w swojej wizji chciał uniknąć materialistycznego $\mathrm{i}$ indywidualistycznego pojmowania praw człowieka ${ }^{41}$.

\section{PODSUMOWANIE}

Podsumowując, chciałbym podkreślić trzy punkty, cały czas opierając się na ideach proponowanych przez Maritaina. Po pierwsze, aby podjąć decyzję, musimy odnieść się do integralnego i złożonego spojrzenia na człowieka, to znaczy nie tylko na wymiar fizyczny, ale także na aspekt wewnętrzny, duchowy. Biorąc pod uwagę ontologiczne spojrzenie na człowieka, patrzymy na niego ze wszystkich stron, a pojęcie rzeczywistości jest pojmowane zarówno w sensie materialnym, jak i „ekstramentalnym". Umożliwia to podjęcie decyzji najbardziej obiektywnej, zarówno ze strony osoby towarzyszącej choremu, jak i samemu pacjentowi. Po drugie, perspektywa personalistyczna pozwala nam uznać godność za wymiar człowieka, który nie może zostać utracony. Byt ludzki może stracić poczucie godności. Niemniej jednak, nie może stracić swojej godności jako takiej, ponieważ stanowi ona element konstytutywny każdego człowieka. Ta myśl jest bardzo istotna, ponieważ już ukierunkowuje każdą decyzję medyczną na korzyść człowieka, w ten sposób, aby go chronić i troszczyć się o jego dobra uniwersalne (np. życie, integralność wewnętrzna). Trzecim elementem, który konstytuuje relację między opiekunem a pacjentem jest wymiar racjonalny każdej decyzji medycznej. W naszej refleksji podkreśliliśmy transcendentny wymiar człowieka. Jego zdolności inteligencji i woli wskazują nam na fakt, że człowiek musi być ujmowany integralnie: w wymiarze cielesnym i duchowym. Ponadto, byt ludzki jest zdolny przekraczać swój własny intelekt; dlatego jest on ciągle otwarty na poznanie (intelekt) i na miłość (wola) ${ }^{42}$. Decyzja medyczna jest zatem ściśle związana z naturalnymi zdolnościami człowieka. Z powyżej refleksji wynika, że poprzez swoją naturę, a także z pomocą innych, człowiek jest w stanie dokonać obiektywnego wyboru. Nawet jeśli każdy z uczestników danej sytuacji medycznej ma inną rolę do spełnienia, w zależności od tego, czy jest on osobą chorą, lekarzem, kapelanem czy członkiem rodziny, bierze on udział w sytuacji medycznej na swój sposób tak, aby decyzja nie była

${ }_{41}$ Por. G. Puppinck, Les droits de l’homme dénaturé, Éditions du Cerf, Paris 2018, s. 49-52.

42 Jacques Maritain używa czasownika surexister, aby podkreślić ową zdolność człowieka do przekraczania wymiaru materialnego i jego otwartość na Absolut. Filozof francuski ujmuje człowieka jako zdolnego do przekraczania siebie samego przez inteligencję i przez wolę (,l'homme est capable de surexister en connaissance et en amour"). Por. J. Maritain, Réflexions sur la personne humaine et la philosophie de la culture, Euvres Complètes, tome VI, 1984, s. 904. 
sprzeczna z naturą człowieka i najwyższym celem (dobrem), do którego dąży. Racjonalność decyzji wyraża się także poprzez fakt, że działanie, jakie z niej wynika, jest zgodne z naturą danego czynu (z jego wymiarami: ontologicznym i gnozeologicznym). Praktyczne zastosowanie pojęcia osoby prowadzi do pewnego porządku w relacjach międzyludzkich. Do najważniejszych należy harmonia relacji między pacjentem a opiekunem, zaufanie i właściwy wizerunek opiekuna, jako tego, który traktuje swoją pracę jako powołanie. W takiej perspektywie mówimy o charakterze partnerskim w relacji z pacjentem. Sztuka medycyny to oczywiście profesjonalizm w diagnostyce i terapii, ale także spotkanie dwóch osób, które reprezentują te same wartości osobowe. Akcentujemy owo ponadczasowe znaczenie tych wartości, ponieważ jako takie, te wartości humanizują relacje międzyludzkie i wskazują drogę indywidualnego i wspólnotowego rozwoju. Nasze analizy związku między personalistyczną koncepcją człowieka a relacjami międzyludzkimi pokazują nam istotny fakt, że sama relacja i jej jakość ma wartość terapeutyczną, leczniczą, stanowi konstytutywną część opieki nad pacjentem i pozwala podjąć decyzję opartą na dialogu z pacjentem (a nie na monologu). Analiza personalistyczna człowieka w świetle myśli Maritaina pozwala nie tylko podkreślić fakt, że każdy pacjent jest wyjątkowy, ale także pogłębić własne relacje opiekuna z jego pacjentami i być świadomym osobliwości każdego cierpienia. To powoduje, że każde spotkanie z osobą chorą jest zawsz inne, wyjątkowe i partykularne. Istnieje bowiem niebezpieczeństwo skupienia się na zewnętrznym aspekcie chorego, co powoduje dystans między opiekunem a pacjentem. Ogląd personalistyczny pozwala uniknąć owego dystansu. Wówczas decyzja medyczna wynika ze współpracy i oparta jest na konkretnej, a szczególnie integralnej wizji człowieka.

\section{Bibliografia}

Andorno R., La bioéthique et la dignité de la personne, Coll. « Médecine et Société », Presses Universitaires de France, Paris 1997.

Benoît XVI, Discours à l'Académie pontificale pour la vie, le 13 février 2010, https://w2.vatican.va/content/vatican/fr.html (14.05.2019).

Cichosz W., Implikacje pedagogiczne antropologii Maritaina, „Studia Gdańskie", 13(2000), s. 159-173.

Collaud T., Le statut de la personne démente, Academic Press Fribourg, Fribourg 2003.

Colliere M.-F., L'apport de l'anthropologie aux soins infirmiers (note de recherche), „Anthropologie et Société”, 14(1990)1, s. 115-123.

Ferry L., The New Ecological Order, University of Chicago Press, Chicago 1995.

Fiat É., Petit traité de dignité. Grandeurs et misères des hommes, Larousse, Paris 2010. 
Grzybowski J., Jacques Maritain i nowa cywilizacja chrześcijańska, Fronda, Warszawa 2007.

Jean Paul II, Le discours aux chirurgiens polonais, 11 février 1992, „L'Osservatore Romano", 13(1992), s. 29-30.

Kołodziejczak W., Jacques Maritain - u źródeł współczesnych koncepcji praw czlowieka, „Studenckie Zeszyty Naukowe”, 26(18)2015, s. 17-25.

Kowalczyk S., Człowiek i społeczność. Zarys filozofii społecznej, Wyd. KUL, Lublin 2005.

Kowalczyk S., Wprowadzenie do filozofii J. Maritaina, Wyd. KUL, Lublin 1992.

Król B., Osobowość, wolność i rozumność człowieka w świetle wybranych dziet Jacques'a Maritaina, „Studia Teologiczno-Historyczne Śląska Opolskiego”, (2014)34, s. 53-66.

Lendzion A., Koncepcja podmiotu osobowego w personalizmie Jacques'a Maritaina, ,Roczniki Pedagogiczne”, 2(2010)38, s. 5-20.

Maritain J., Antimoderne, Euvres Complètes, tom II, 1987.

Maritain J., Court traité de l'existence et de l'existent, Euvres Complètes, tom IX, 1990.

Maritain J., La loi naturelle ou la loi non écrite, Euvres Complètes, tom XVI, 1999.

Maritain J., Les Droits de l'homme et la loi naturelle, Euvres Complètes, tom VII, 1988.

Maritain J., Natural Law and Moral Law, w: Moral Principles of Action. Man's Ethical Imperative, red. R.-N. Anshen, Coll. « Science of Culture Series », Volume VI, Harper and Brothers, New York 1952.

Maritain J., Neuf leçons sur les notions premières de la philosophie morales, Téqui, Paris 1951.

Maritain J., Principes d'une politique humaniste, Euvres Complètes, tom VIII, 1989.

Maritain J., Raison et raisons, Euvres Complètes, tome IX, 1990.

Maritain J., Réflexions sur la personne humaine et la philosophie de la culture, Euvres Complètes, tome VI, 1984.

Maritain J., Sept leçons sur l'être et les premiers principes de la raison spéculative, Euvres Complètes, tom V, 1982.

Maritain J., Trois réformateurs: Luther-Descartes - Rousseau, Euvres Complètes, tom III, 1984.

Mazurek F. J., J. Maritaina koncepcja Praw Człowieka, w: Jacques Maritain prekursor soborowego humanizmu, red. E. Balawajder, S. Kowalczyk, Wyd. KUL, Lublin 1992, s. 155-169.

Michałek T., Jacques 'a Maritaina koncepcja ,,szóstej drogi”, „Roczniki Filozoficzne", 43/44(1995-1996)2, s. 135-159. 
Niessen F., Dinechin O. De, Repères chrétiens en bioéthique, la vie humaine du début à la fin, Editions Salvator, Paris 2015.

Niesyty E., Miejsce i rola personalistycznej koncepcji społeczeństwa demokratycznego w humanizmie integralnym Jacques'a Maritaina, Instytut Filozofii UAM, Poznań 2005.

Petit J.-F., Philosophie et théologie dans la formation du personnalisme d'Emmanuel Mounier, Les Éditions du Cerf, Paris 2006.

Puppinck G., Les droits de l'homme dénaturé, Éditions du Cerf, Paris 2018.

Rognon F., Vers une éthique de la vulnérabilité. Responsabilité face à la haute technicité et reconnaissance du sujet, w: Souhaitable vulnérabilité?, red. M. Jo-Thiel, Coll. Chemins d'éthique, Presses Universitaires de Strasbourg, Strasbourg 2016.

Sadowski M., Personalizm chrześcijański Jacques'a Maritaina jako fundament koncepcji godności czlowieka, http://www.bibliotekacyfrowa.pl/Content/35301/0004. pdf, (17.052019).

Tomasz z Akwinu, Summa Theologiae, thum A.-M. Roguet, Les Editions du Cerf, Paris 1984-1986.

Wasyluk P., Między optymizmem i pesymizmem dziejowym - Jacques'a Maritaina koncepcja realizmu historiozoficznego, „Roczniki Filozoficzne”, 60(2012)2, s. 5-23. 